\title{
Pelatihan Manajemen Tentang Badan Usaha Milik Desa Bagi Perangkat Desa Dan Kelompok Kerja
}

\author{
Dianawati Suryaningtyas \\ Universitas Kanjuruhan Malang; diana_surya@unikama.ac.id
}

\begin{abstract}
Badan Usaha Milik Desa (BUMDes) is a government program aims to build community welfare through independent economic. To build BUMDes is obligated to all district which has been given socialization dan training about this enterprise by local government. This community service was conducted in Pakisjajar aims to help"perangkat desa" and "kelompok kerja (Pokja)" with management knowledge in oder to build BUMDes. The result of training showed that all participants antusiastic by asking many questions and discussing their problems. As the training ended, all participants stated that they satisfied with the material of training. It was complete and met their needs and they felt sure to build BUMDes. Hopefully, participants of this training can build BUMDes as soon as possible and can manage the enterprise succesfully.
\end{abstract}

Keywords: Management; BUMDes; UU No. 6 Tahun 2014; kelompok kerja (Pokja); Pakisjajar

\begin{abstract}
Abstrak
Badan Usana Milik Desa (BUMDes) merupakan program pemerintah yang bertujuan untuk memakmurkan desa melalui perekonomian yang mandiri. Badan usaha ini wajib didirikan oleh semua desa yang telah mendapatkan sosialisasi dan pelatihan dari pemerintah daerah kabupaten. Pengabdian kepada masyarakat ini dilaksanakan di desa Pakisjajar dengan tujuan untuk membekali perangkat desa dan kelompok kerja (Pokja) dengan ilmu manajemen agar pelaksanaan pendirian BUMDesa dapat segera dilaksanakan dengan mantap dan berhasil. Hasil pelatihan menunjukkan peserta sangat antusias dalam mengikuti pelatihan dan mengajukan berbagai pertanyaan dan mendiskusikan masalah-masalah yang mereka hadapi sebelumnya. Diakhir pelatihan peserta menyatakan bahwa materi pelatihan sangat lengkap dan sesuai dengan yang dibutuhkan peserta dan seluruh peserta merasa mantap untuk segera melaksanakan pendirian BUMDes. Pelatihan ini diharapkan agar peserta dapat segera memenuhi kewajiban dari pemerintah untuk mendirikan BUMDes dan mengelolanya dengan sukses.
\end{abstract}

Kata kunci: Manajemen; BUMDes; UU No. 6 Tahun 2014; kelompok kerja (Pokja); Pakisjajar 


\section{A. PENDAHULUAN}

\section{Analisis Situasi}

Wilayah Desa Pakisjajar merupakan desa yang cukup maju dan merupakan salah satu desa yang dikelilingi banyak perusahaan dan pabrik di kecamatan Pakis Kabupaten Malang. Perusahaan yang berlokasi di wilayah desa ini berjumlah 40 perusahaan. Wilayah ini cukup luas dan merupakan perbatasan wilayah ke kota Malang. Desa ini sudah selayaknya kota karena banyaknya jumlah penduduk dan perusahan sehingga ciri khas desa yaitu wilayah yang penuh dengan hasil pertanian sudah tidak nampak lagi. Sehingga banyak penduduk yang mata pencahariannya sebagai pekerja di pabrik atau perusahaan di wilayah tersebut. Dengan kondisi banyaknya pabrik dan perusahaan di desa Pakisjajar ini, telah menggeser kehidupan desa menjadi seperti kehidupan selayaknnya di kota, namun didalam hal pemberdayaan sumber daya manusia, desa ini masih membutuhkan bantuan dalam hal pelatihan dan pengembangan.

Saat ini pemerintah telah memiliki program pemberdayaan desa yaitu Badan Usaha Milik Desa disingkat BUMDes yang merupakanrealisasi UU No. 6 Tahun 2014tentang Desa. Jika pada tingkat pusat dikenal Badan Usaha Milik Negara (BUMN), di tingkat provinsi atau kabupaten/kota dikenal dengan Badan Usaha Milik Daerah (BUMD), maka di desa dikenal dengan BUMDes.Badan usaha ini, menurut Pasal 1 ayat 6 UU Desa, adalah badan usaha yang seluruh atau sebagian besar modalnya dimiliki oleh desa melalui penyertaan secaralangsung yang berasal dari kekayaan desa yang dipisahkan guna mengelola aset, jasa pelayanan, dan usaha lainnya untuk sebesar-besarnya kesejahteraan masyarakat desa. Kementerian Desa Pembangunan Daerah Tertinggal (PDT) dan Transmigrasi memproyeksikan pendirian 5000 BUMDes. Hinggaakhir tahun 2015 ternyata sudah berdiri sekitar 12.115 BUMDes yang tersebar di 74 kabupaten, 264 kecamatan dan 1022 desa. Dari mana diperoleh dana untuk permodalan? Sebagian memanfaatkan dana desa yang totalnya Rp20,7 triliun tahun 2015 (Malik, 2016).

Pendirian BUMDes memunculkan beberapa persoalan. Penelitian Pusat Telaah dan Informasi Regional menemukan fakta tentang pendirian BUMDes seperti untuk menggali potensi desadan menyesuaikan dengan kondisi riil desa. Ada yang berupa simpan pinjam.Salah satu persoalan yang ditemukan adalah struktur dan bentuk badan usaha.Strukturnya masih didominasipendiri, sehingga peran Badan Permusyawaratan Desa (BPD) masih kurang. Badan usaha ada yang menggunakan koperasi, CV, bahkan perseroan terbatas. Pendirian BUMDes tergantung pemerintah desa dan warga desa, yang diatur dalam Peraturan Desa (Perdes). Berdasarkan Pasal 88 UU Desa, BUMDes dibentuk melalui musyawarah desa.Pengaturan lebih lanjut dimuat dalam Peraturan Menteri Desa PDT dan Transmigrasi No. 4 Tahun 2015, yang diundangkan 18 Februari 2015. Ada beberapa prinsip yang penting untuk dipahami, yaitu (Malik, 2016):

1. Payung hukum pendirian. BUMDes dibentuk melalui Perdes. Sesuai konsep UU No. 6 Tahun 2014, maka Perdes itu juga harus dicatatkan di Lembaran Desa.

2. Undang-Undang hanya mensyaratkan BUMDes didirikan melalui Musyawarah Desa.

3. Pendirian BUMDes harus disesuaikan dengan kondisi ekonomi, sosial budaya masyarakat.

4. Struktur Organisasi BUMDes terdiri dari penasihat,pelaksana operasional, dan pengawas. 
5. Modal usaha BUMDes adalah milik desa. Jika modal berasal dari kekayaan desa, maka kekayaan desa itu harus dipisahkan. Terdapat peluang bagi pihak ketiga untuk menanamkan modal di BUMDes.

6. Mempersiapkan Anggaran Dasar dan Anggaran Rumah Tangga BUMDes.

\section{Permasalahan Mitra}

Situasi terakhir yang ada di desa Pakisjajar kecamatan Pakis kabupaten Malang saat ini adalah pemerintah kabupaten baru saja mengundang dan memberikan pelatihan tentang pendirian BUMDes kepada perangkat desa dan beberapa kader desa karena awal tahun depan BUMDes sudah harus didirikan di desa Pakisjajar. Kelompok kerja (Pokja) sudah dibentuk dan akan memulai bekerja. Namun perangkat desa dan Pokja belum memahami tentang bagaimana proses dan cara mendirikan BUMDes, persiapan dan pengelolaannya. Selain itu, adanya perbedaan pendapat diantara para kader desa dan perangkat desa menyebabkan tidak segera didapatkan titik temu atau kata sepakat untuk segera mendirikan BUMDes. Hal ini disebabkan oleh kurangnya pengetahuan dan pemahaman tentang BUMDes dan manajemen. Berdasarkan fakta yang ada di lapangan, maka kegiatan pengabdian kepada masyarakat ini berupaya memberikan solusi bagi permasalahan yang dihadapi.

\section{Solusi yang Ditawarkan}

Solusi yang ditawarkan adalah memberikan pembekalan dan pelatihan manajemen BUMDes. Target sasaran pembelajaran adalah para perangkat desa dan kelompok kerja (Pokja) di desa Pakisjajar Kecamatan Pakis kabupaten Malang.

Partisipasi mitra didalam pelaksanaan pelatihan adalah : 1) Menyediakantempat pelatihan; 2) Menyediakan LCD untuk presentasi; 3) Mengundang peserta yang akan mengikuti pelatihan manajemen, yaitu Kepala desa, perangkat desa,ketua BPD dan Pokja; 4) Menetapkan waktu pelaksanaan pelatihan.

\section{Target Luaran}

Program pengabdian pada masyarakat ini menetapkan target yaitu tercapainya keinginan masyarakat untuk memiliki BUMDes, yang akan bermanfaat bagi peningkatan perekonomian di desa Pakisjajar kecamcatan Pakis kabupaten Malang. Sedangkan luaran dari pengabdian ini adalah berupa pengalihan pengetahuan (knowledge transfer). Tujuannya adalah untuk meningkatkan skills seluruh peserta pelatihan berupa peningkatan wawasan dan pengetahuan manajemen agar mereka memiliki kemampuan yang benar dalam mewujudkan pendirian BUMDes dan dapat mengelolanya dengan benar dan baik.

\section{B. METODE PELAKSANAAN}

\section{Rencana Kegiatan}

Rencana kegiatan yang akan dilakukan untuk membantu menyelesaikan permasalahan perangkat dan warga desa Pakisjajar dapat digambarkan sebagai alur proses seperti Gambar 1 di bawah ini:

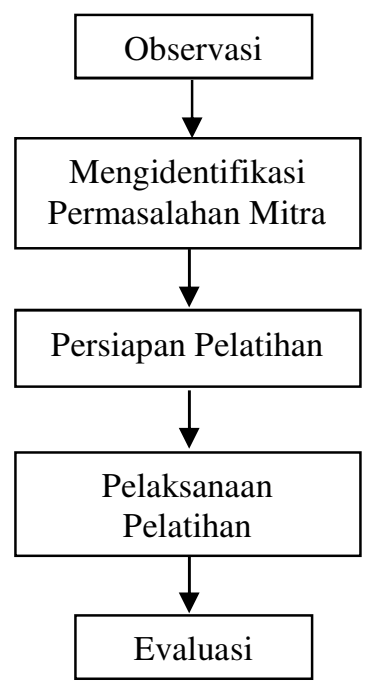

Gambar 1. Alur Proses Pelaksanaan Pelatihan 


\section{Metode Pendekatan}

Metode pendekatan yang dilakukan dalam kegiatan pengabdian ini adalah dengan melakukan pembicaraan dengan kepala desa, sekretaris desa, dan ketua LKMD selaku mitra untuk mencapai kesepakatan. Selanjutnya pengabdi menemui kepala bidang pemberdayaan desa kabupaten Malang. Hasil diskusi dengan kepala bidang tersebut mengarah pada pengidentifikasian permasalahan mitra dan solusi yang dapat ditawarkan kepada mitra. Langkah selanjutnya adalah menemui mitrauntuk keperluan persiapan pelaksanaan kegiatan.

\section{Pelaksanaan Kegiatan}

Persiapan pelaksanaan kegiatan dibantu oleh mitra dengan menentukan dan mengundang peserta pelatihan. Mitra juga membantu persiapan peralatan dan perlengkapan yang dibutuhkan dalam pelaksanaan pelatihan. Pelatihan diadakan pada di Balai Desa Pakisjajar yang dihadiri oleh 20 peserta yang terdiri dari perangkat desa, kelompok kerja (Pokja), dan Badan Pengawas Desa. Pelatihan yang diberikan adalah presentasi dan tanya jawab membahas masalah yang dihadapi oleh peserta.

\section{HASIL DAN PEMBAHASAN}

Hasil dari setiap tahapan proses pelaksanaan pelatihan diuraikan berdasarkan urutan kegiatan yang dilakukan beserta pembahasannya, yaitu :

\section{Tahap Observasi dan Persiapan}

Pada tahap ini observasi dilakukan dengan perangkat desa, diperoleh informasi bahwa sebelumnya sudah pernah mendapatkan sosialisasi tentang pendirian BUMDes dari kepala bidang pemberdayaan desa kabupaten Malang. Namun perangkat desa dan warga desa Pakisjajar memiliki perbedaan pendapat yang hingga saat ini belum mencapai kesepakatan. Kedatangan pengabdi untuk menawarkan solusi mendapatkan respon yang positif. Selanjutnya pendekatan dengan kepala bidang pemberdayaan desa kabupaten Malang. Ternyata dalam waktu dekat desadesa yang hingga saat ini belum mendirikan BUMDes akan dipanggil dan diberikan pelatihan, untuk selanjutnya wajib mendirikan BUMDes awal tahun depan. Hasil diskusi dengan kepala bidang tersebut adalah pengabdi diminta untuk memberikan pelatihan manajemen BUMDes. Tahap observasi ini kemudian ditindaklanjuti dengan persiapan tempat serta peralatan pelatihan dan mengundang peserta pelatihan yang dilakukan oleh mitra.

\section{Tahap Pelaksanaan}

Pelatihan manajemen dilaksanakan dalam dua sesi. Sesi pertama pelatihan dilaksanakan oleh pengabdi dengan materi "Pendirian BUMDes dan Manajemen BUMDes". Pelatihan ini mengajarkan bagaimana langkah-langkah didalam proses pendirian BUMDes yang dibutuhkan peserta terutama kelompok kerja (Pokja) untuk segera dapat bekerja dan mewujudkan pendirian BUMDes.

Langkah-langkah tersebut menurut Lelono (2016) adalah: 1) Mengadakan musyawarah desa untuk mencapai kesepakatan pendirian BUMDes; 2) Merumuskan pendirian BUMDes, organisasi pengelola BUMDes, modal usaha BUMDes, dan Anggaran Dasar / Anggaran Rumah Tangga BUMDes; 3) Menetapkan peraturan desa tentang pendirian BUMDes; 4) Pendirian BUMDes.

Pelatihan ini juga memberikan pemahaman tentang struktur organisasi dan tata kelola organisasi yang benar yang 
dibutuhkan dalam pendirian BUMDes. Beberapa pertanyaan diajukan dalam pelatihan ini, termasuk diantaranya adalah penetapan bentuk badan usaha, struktur organisasi BUMDes dengan mekanisme wewenang dan tanggung-jawab, kriteria perekrutan manajer unit dan budaya organisasi yang harus dibangun dalam pendirian BUMDes.Struktur organisasi BUMDes yang diusulkan dalam pelatihan seperti yang digambarkan dalam Gambar 2 sebagai berikut:

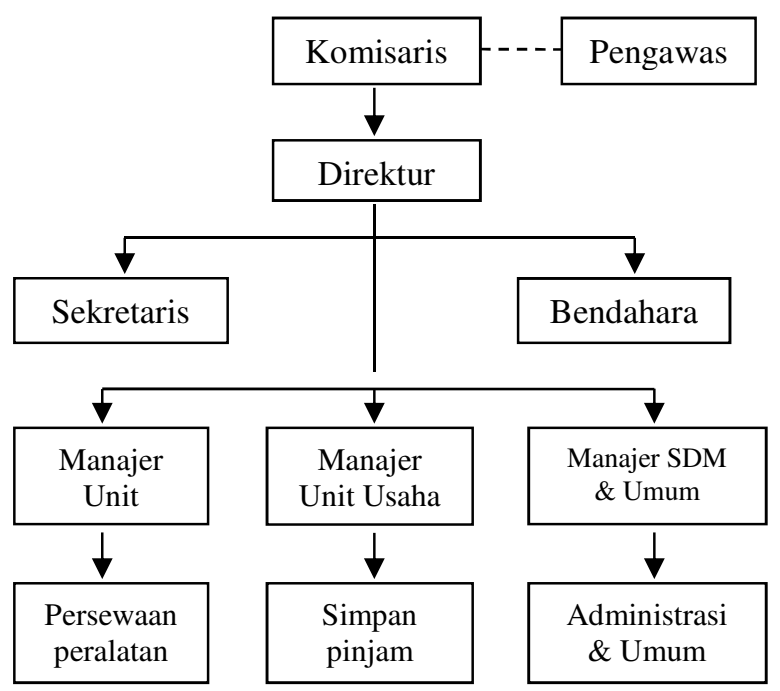

Gambar 2. Struktur Organisasi BUMDes

Di dalam struktur organisasi BUMDes tersebut, yang menjabat sebagai komisaris adalah kepala desa yang berfungsi sebagai penasehat, sedangkan pengawas dijabat oleh Badan Pengawas Daerah yang berfungsi mengawasi. Sedangkan jabatan Direktur, Manajer, sekretaris, bendahara dan staf direkrut secara profesional sesuai dengan kompetensinya masing-masing dan berfungsi sebagai pelaksana. Didalam pengelolaan operasional BUMDes seharihari, perangkat desa tidak diperkenankan ikut campur agar pelaksana dapat bekerja secara mandiri. Dengan demikian fungsifungsi manajemen dapat berjalan dengan baik. Posisi Manajer Sumber Daya Manusia (SDM) dan Umum dibutuhkan jika unit- unit usaha cukup banyak dan diperlukan pengelolaan SDM dan bagian yang menangani urusan umum. Agar pengelolaan operasional organisasi dapat berjalan dengan baik, maka fungsi-fungsi manajemen harus dilaksanakan, yaitu : perencanaan, pengorganisasian, pengarahan, dan pengawasan (Ridhotulloh \& Jauhar, 2015).

Peserta juga mengajukan beberapa pertanyaan terkait permasalahan yang dihadapi mitra yaitu perbedaan pendapat diantara peserta pelatihan dan warga desa. Materi pelatihan yang dipresentasikan telah memberikan pemahaman akan ilmu pengetahuan manajemen yang dibutuhkan bagi peserta dalam proses pelaksanaan pendirian BUMDes. Pelaksanaan pelatihan manajemen BUMDes tersebut didokumentasikan sebagai berikut :

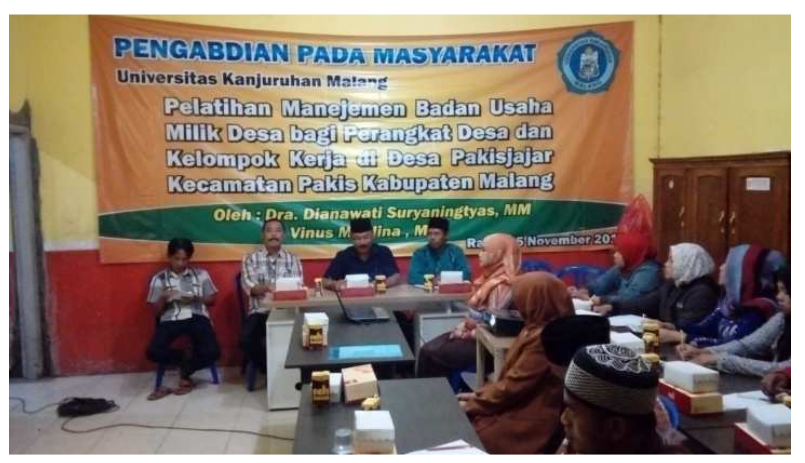

Gambar 3. Foto menunjukkan seluruh peserta dan pemateri sedang mengikuti pembawa acara yang memulai memandu acara.

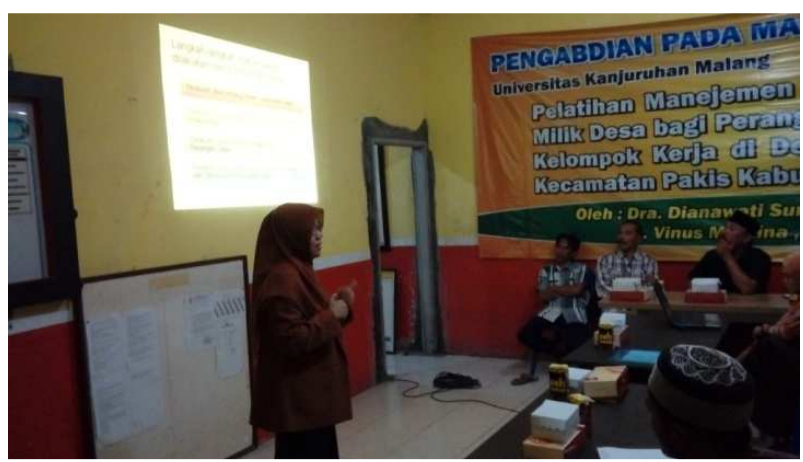

Gambar 4. Sesi pertama, pemateri sedang melakukan presentasi dengan tema "Pendirian BUMDes dan Manajemen BUMDes". 


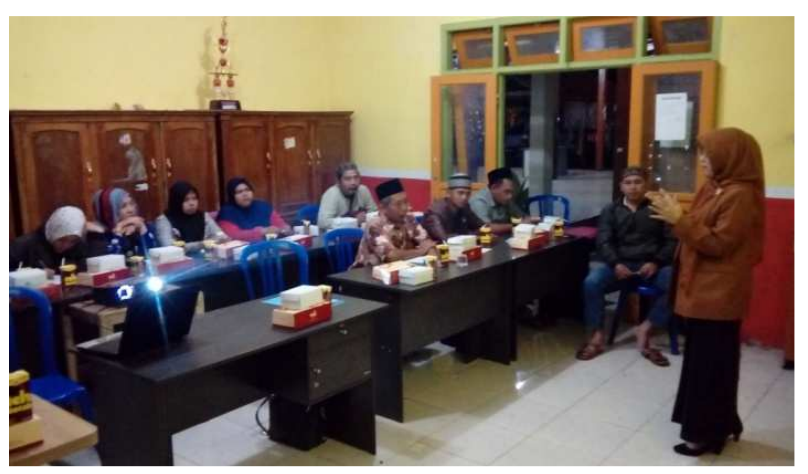

Gambar 5. Pemateri pertama sedang menjawab pertanyaan-pertanyaan dari para peserta.

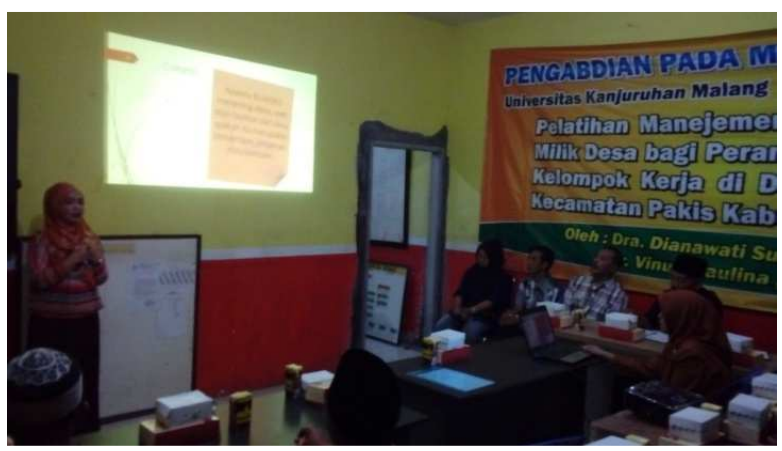

Gambar 6. Pemateri kedua sedang melakukan presentasi dengan tema "Mekanisme dan Administrasi Penyertaan Modal dari Desa“"

Sesi selanjutnya pelatihan manajemen yang memfokuskan pada permodalan disampaikan oleh pemateri yang mendukung pengabdi dalam pelaksanaan pengabdian ini. Pelatihan inimengambil tema "Mekanisme dan Administrasi Penyertaan Modal dari Desa". Pemateri pendukung juga mendapatkan beberapa pertanyaan dari pesertatermasuk modal yang dibutuhkan, modal berasal darimana, dan bagaimana pembuatan laporan keuangan. Permodalan Badan Usaha Milik Desa dapat berasal dari (Lelono, 2016):

1. Pemerintah Desa;

2. Tabungan masyarakat;

3. Bantuan Pemerintah Provinsi dan Pemerintah
Kabupaten / Kota;

4. Pinjaman; dan/atau

5. Penyertaan modal pihak lain atau kerja sama bagi hasil atas dasar saling menguntungkan.

Dalam sesi ini, masalah yang dihadapi peserta terkait dengan permodalan telah mendapatkan solusi yang memuaskan peserta. Bahkan salah satu peserta menyatakan akan menanamkan modal dalam jumlah yang cukup besar.

\section{Tahap Evaluasi}

Sebelum pelatihan diakhiri, ketua kelompok (Pokja) memberikan evaluasi pelaksanaan pelatihan yang baru saja berlangsung. Secara keseluruhan, materi yang disampaikan adalah sangat lengkap dan merupakan pengetahuan yang benarbenar mereka butuhkan dalam proses pendirian BUMDes. Semua pertanyaan yang diajukan oleh peserta telah terjawab dengan memuaskan. Beberapa permasalahan dan perbedaan pendapat yang selama ini terjadi diantara mereka terkait pendirian BUMDes telah mendapatkan solusi yang memuaskan.

\section{PENUTUP}

\section{Simpulan}

Program pengabdian kepada masyarakat tentang pelatihan manajemen BUMDes bagi perangkat desa dan kelompok kerja (Pokja) di desa Pakisjajar telah memberikan solusi bagi seluruh peserta pelatihan yaitu yang pertama, kelompok kerja (Pokja) lebih memahami langkah-langkah membuat rencana kerja untuk pelaksanaan pendirian dan pengelolaan BUMDes; kedua, perangkat desa lebih memahami peran dan kedudukannya dalam pendirian dan pengelolaan BUMDes; ketiga, seluruh peserta pelatihan lebih memahami fungsi 
JPM (Jurnal Pemberdayaan Masyarakat)

ISSN 25411977 (Print) E- ISSN 2615-2649 (Online) Vol. 3 No. 12018 http://ejournal.unikama.ac.id/index.php/jpm

dan cara kerja serta manajemen BUMDes. Sehingga dapat disimpulkan bahwa tema dari materi yang disampaikan oleh kedua pemateri sangat tepat dan benar-benar memberikan solusi terhadap kendala maupun permasalahan yang mereka hadapi dalam proses pendirian dan pengelolaan BUMDes.

\section{Saran}

Pelatihan yang dilakukan sebaiknya ditindak-lanjuti dengan pendampingan saat peserta mulai melaksanakan pendirian BUMDes agar dapat dilaksanakan dengan benar dan meminimalkan kemungkinan terjadinya perselisihan atau perbedaan sikap dan pendapat yang dapat menghambat pelaksanaannya.

\section{E. DAFTAR PUSTAKA}

Lelono, J. 2016. Paparan BUMDes. dagangan.madiunkab.go.id/downlot.p hpfie.pptx

Malik, M. 2016. Menggerakkan Ekonomi Desa Melalui Badan Usaha Milik Desa Secara Berkelanjutan. Direktorat Pengembangan Usaha Ekonomi Desa, Kemendes, PDT dan Transmigrasi.

Ridhotulloh, S dan Jauhar, M, 2015. Pengantar Manajemen. Prestasi Pustaka. Jakarta. 